\title{
Level of written communication, linguistic deficiencies, and the achievement of competences in incoming students in an Universidad Pública del Cusco
}

\section{Nivel de comunicación escrita, deficiencias lingüísticas, y el logro de competencias en estudiantes ingresantes en una Universidad Pública del Cusco}

\author{
VELASCO-PALACIOS, María Dolores†* \& SUYO-CRUZ, Gabriel \\ Universidad Nacional de San Antonio Abad del Cusco, Peru. \\ ID $1^{\text {st }}$ Author: María Dolores, Velasco-Palacios / ORC ID: 0000-0001-6978-4112 \\ ID $1^{\text {st }}$ Co-author: Gabriel, Suyo-Cruz / ORC ID: 0000-0002-9490-403X
}

DOI: $10.35429 /$ JTER.2021.19.7.17.27

Received January 25, 2021; Accepted June 30, 2021

\begin{abstract}
Currently, the education environment is experiencing great challenges; In other words, education in Peru, especially Regular Basic Education (EBR), presents a series of difficulties in the writing of administrative and academic documents. The objective of the study is to establish the relationship between the level of written communication, the linguistic deficiencies, and the achievement of competences in students entering an Universidad Pública del Cusco. The study approach is quantitative and applicative, with a causal correlational cross-sectional design; It is made up of a total of 1406 students entering the National University of San Antonio Abad del Cusco, choosing for the study of 142 students through non-probability sampling for convenience, compiling the information using the Likert scale, having examined its validity and reliability. Obtaining the fundamental conclusions that if there is a significant association between the level of written communication, linguistic deficiencies, and the achievement of competencies in students entering an Universidad Pública del Cusco. As well as it is observed with the contrast of the hypothesis test whose "P-value" $=0.000$ is less than the significance value 0.05 . Evidence using the Rho Spearman statistical test denies the null hypothesis, and we admit the alternative hypothesis.
\end{abstract}

Level of written communication, Linguistic deficiencies, Achievement of competences

\begin{abstract}
Resumen
En la actualidad, el entorno de educación está sufriendo grandes desafíos; es decir, la educación en el Perú, especialmente Educación Básica Regular (EBR), presenta una serie de dificultades en la redacción de los documentos administrativo y académicos. El objetivo de estudio es establecer la relación entre el nivel de comunicación escrita, las deficiencias lingüísticas, y el logro de competencias en estudiantes ingresantes en una Universidad Pública del Cusco. El enfoque de estudio es cuantitativo y aplicativo, con un diseño transversal correlacional causal; está conformada por un total de 1406 estudiantes ingresantes a la Universidad Nacional de San Antonio Abad del Cusco, eligiendo para el estudio de 142 estudiantes a través del muestreo no probabilístico por conveniencia, compilando la información mediante la escala de Likert, habiendo examinado su validez y confiabilidad. Obteniendo las conclusiones fundamentales que, si existe una asociación significativa entre el nivel de comunicación escrita, las deficiencias lingüísticas, y el logro de competencias en estudiantes ingresantes en una Universidad Pública del Cusco. Así como, se observa con el contraste de la prueba de hipótesis cuyo "P-value" = 0,000 es menor que el valor de significancia 0,05 . Evidencia mediante la prueba estadístico de Rho Spearman se deniega la hipótesis nula, y admitimos la hipótesis alternativa.
\end{abstract}

Nivel de comunicación escrita, Deficiencias lingüísticas, Logro de competencias

Citation: VELASCO-PALACIOS, María Dolores \& SUYO-CRUZ, Gabriel. Level of written communication, linguistic deficiencies, and the achievement of competences in incoming students in an Universidad Pública del Cusco. Journal of Teaching and Educational Research. 2021. 7-19:17-27.

\footnotetext{
* Correspondence to the Author (Email: maria.velasco@unsaac.edu.pe)

$\uparrow$ Researcher contributing as first author.
} 


\section{Introduction}

The community of cognition and communication has innovated the forms of employment, the processes of social, economic, cultural, philosophical, ideological and educational organization in humanity for more than three decades. This has led to facing new challenges, new learning concepts and the mastery of competences, both at an individual, interpersonal, social and work level, under a lifelong teaching approach.

Higher education, such as public universities, currently seek society to improve communication, the responsibility of creating knowledge in these university classrooms, and all of this leads us to a general problem (Arciniegas Lagos and López Jiménez, 2012). They help provide General Studies students to develop knowledge, thus initiating daily learning; With this, skills are improved and this is directly reflected in their production of texts. Indeed, linguistic discipline is essential for undergraduate students, in professional schools, they must have knowledge of the time and the facilitator's ability to support the process of writing the speech.

The process of written communication with students is a preponderant factor where the explicit writing of orality triangulation, where these elements are essential at the time of exchange of information and experience. The sender is the person who initiates the communication, the listener receives the speaker's report and the content is found in the message. And all this, a code must be managed so that there is effective communication.

The semantic deficiency is associated with the level of the content of the linguistic sign with meaning and interpretation of the words; Likewise, in expressions it must have meaning and syntactic autonomy to be able to assimilate in written and oral communication. The speaker and listener must handle the technical terms related to the specialty so that there is efficient communication, this implies that the student must practice reading to become familiar with the words, which carries a social pragmatic sense.
At the level of university students of higher level they do not seriously practice the writing of academic, administrative, literary and scientific documents. This is observed in the production of their texts that they do not perform as they should be, where disinterest, apathy, and indifference prevail when producing the different texts. Likewise, the learning evidences have deficiencies: semantic, syntactic, grammatical, morphological, phonological and pragmatic. Therefore, it is proposed to work with higher-level students, to improve their generic learning skills that will help in academic and scientific training. All this is summarized in the achievement of competencies of the students entering a Public University.

Therefore, students from all professional schools must have management and knowledge of oral and written expression, to put into practice the production of different texts and this will serve to improve their academic, scientific and technological professional training.

In the production of texts, the development of teaching-learning participates a fundamental and substantial role, primarily the transparent interpretation that is not processed as a whole, less the accumulation and simplicity of ideas to form an argument of the context.

In reality, in the General Studies students of the National University of San Antonio Abad del Cusco (UNSAAC), different problematic realities are observed, especially in written communication. Likewise, in oral expression they have difficulties facing the stage and sustaining their exhibitions of commissioned works. In the same way, students have communication deficits because they do not use the linguistic code correctly, where there are inconsistencies in their expressions and at the same time they reflect in their written productions. Thus, it is noted that a sentence occupies a paragraph, and the student no longer has coherence in the meaning of the words he expresses. In addition, they construct long sentences without pauses without using the proper grammar spelling rules, which directly influence their expressions, as well as writing short and long texts. Thus, in many circumstances there is a lack of creativity to improve and argue their thoughts, ideas, which they use to produce texts. 
Finally, it requires these students to enrich their lexicons to improve their oral and written communication. In response to which, the research was posed as a question: What relationship exists between the level of written communication, linguistic deficiencies, and the achievement of competencies in students entering an Universidad Pública del Cusco?

\section{Written communication}

Fonseca Yerena, Correa Pérez, Pineda Ramírez, and Lemus Hernández (2011) stated that communication is the social interaction that occurs between the interlocutors. Gutiérrez Castillo, López Heredia, Salazar González, and Ibarra Ramírez (2012) stated that it is the interaction of information towards oneself. In relation, Rojas Saldaña (2013) indicated that communication is the exchange of the communicative process, which is carried out using linguistic signs and serves to inform and remember meanings. That is, to communicate is to make known everything that we evoke from experiences making use of linguistic and nonlinguistic communication.

Currently, in universities teaching in relation to the Spanish language has become outdated; In other words, the teaching of Regular Basic Education with the University does not have an adequate articulation; for this reason, there are these unevenness or lags and there is no real concretion. On the other hand, scientific theoretical knowledge that is related to linguistic sciences must be put into practice, such as: Sociolinguistics, psycholinguistics, pragmatics, textual linguistics, discourse analysis and didactics.

Pinales Rodríguez and Lagunas Beltrán (1998, p. 21) affirmed that the language is an executable skill in the resources of the speakers of the language, which they have at their command; Likewise, it is an attitude that makes sense, coherence, availability and possibility of execution, to explain what you want and feel to inform including an individual and personal vision.

Language is a system of linguistic signs; in other words, it is the individual's ability to explain through an integrated communication system, whether by oral or written signs that are part of a defined linguistic context.
So the language is a conventional structure of signs made by society to carry out its communications efficiently and effectively.

All writing has a structure that makes up three relevant elements such as; introduction, development and closure:

a) Introduction: It is the beginning of the production of text, where it captures the situational summary, place, time and the historical sequence.

b) Development: Where all the development of the research content is explained.

c) Closure: It is concluded with the solution of the sequence of the content of the investigation in a summarized and synthetic way.

Cortés Moreno (2000, p. 34) presented that writing is the fundamental basis of every person that requires building words, phrases, sentences and texts. In this understanding, writing helps develop abilities and skills in individuals and with pragmatics it helps improve exercise in cognitive, linguistic, sentimental and social development.

At present we evidence a rapid and relevant innovation in the instruments that provide knowledge and communication. We appreciate the innovations that occur in the community for the use of new ways of communicating through new virtual formats and digital platforms, where communication is mediated and established with available and free accessibility. Written communication is implicit in the linguistic disciplines (semantics, semiotics, phonetics, phonology, syntax, spelling, and grammar), which regulate the rules of linguistic variations, but rather this ability integrates the intrinsic communicative need of the person (Estévez Fuertes et al., 2011).

\section{Purposes of written communication}

To consider the purposes of written communication, it is necessary to accept that oral language as a means of expressive communication, the main purposes are two: Reflect and communicate; that is, express the text with our own words and / or experiences, to later transform it into new knowledge, but respecting the original meaning, in order to reach a better understanding.

VELASCO-PALACIOS, María Dolores \& SUYO-CRUZ, Gabriel. Level of written communication, linguistic deficiencies, and the achievement of competences in incoming students in an Universidad Pública del Cusco. Journal of Teaching and Educational Research. 2021 
In this way, the purpose of written communication is to concretize the information of the reader in an adequate way to express thoughts similar to what the author of the written text transmits. In order for you to achieve your objective of written communication, you should consider the following:

- Write for the reader.

- Establish expressions and introduce readers without expressing bad views.

Use readable, noticeable words and expressions that make complete sense.

Disseminate and examine in detail the first writing.

According to Estévez Fuertes et al. (2011) considered the following dimensions of written communication is based on scientific, literary and administrative writing. That is, writing is a form of dialogue that allows the individual to communicate from a document; In other words, it is a way of exchanging information between two people. In this, the speaker produces different continuous texts (academic articles, essays, novels, literary stories, monographic works, interpretation of texts, among others), with which he seeks to inform his message to the recipients or recipients.

\section{Linguistic deficiencies}

Alonso-Cortés Manteca (2002, p. 11) stated that "it is the scientific study of languages as an international expression of the word". For their part, Mounin and Ter-Sakarian (1979, p. 115) define that the science of language is the study of the purposes and characteristics of composition in the order and development in the context and space of natural human languages. In the same way, the cited intellectuals have similarity in concretizing the scientific characteristics of linguistics; taking into account the pedagogical formation of the phenomena that cooperate in the development of natural languages and the management of knowledge of the interlocutors, with variations that occur in time and space, finally, without variation it is static. In short, the science of linguistics expresses all manifestations of language; that is to say, the knowledge of the scientific investigation of the subject.
Integrating the words deficiency and linguistics, it means that it is the lack or lack of properties of the natural language; likewise, in the management of knowledge and pragmatics of the interlocutors. This research work includes the linguistic disciplines: spelling, pragmatics, semantics, morphology and syntax. These linguistic resources are fundamental bases for the linguistic domain. As stated, Martínez Martínez (2002) is a technique and strategy that do not work properly in the use of semantics and pragmatics; therefore, they admit the relevant requirements in an important way of individual with third parties.

First, it must be distinguished that they are the particular weaknesses and difficulties in the context of speech and language; that is, speech is the individual expression of the person and language is the ability to express thoughts and ideas. In this understanding, the difference between communication, language and speech is added. In other words, communication deals with the interaction between two or more people, in most occasions or circumstances they use linguistic and non-linguistic language. Next, language is the ability to speak ideas, feelings, tendencies, through the use of verbal and nonverbal signs, through which experiences are expressed. Finally, speech refers to the particular expression of the individual in this way has incorporated the physiological and neurological mechanisms. Although, each of these words presented show that they are different in the meaning context, thus evoking that each one has a constant interrelation between these terms. (Godoy Lenz and Zilliani Illanes, 2007)

According to Martínez Solís (2002, p. 46), he stated that the dimensions of linguistic deficiencies consider semantic deficit, syntactic deficit, morphological deficit, and spelling deficit. That is, the construction of texts follows a structure depending on the type of text, to then explain the relevant meaning to the groups. In this way, it is observed that there is a lack in the handling of grammatical orthographic norms, for the elaboration of different documents.
VELASCO-PALACIOS, María Dolores \& SUYO-CRUZ, Gabriel. Level of written communication, linguistic deficiencies, and the achievement of competences in incoming students in an Universidad Pública del Cusco. Journal of Teaching and Educational Research. 2021 


\section{Competencies}

The meaning of aptitude has a close relationship with the ability to handle various complex situations, and this implies that "competence" is fundamental to be applied at the levels of knowledge and the experience of skills to expose and thus lead to communication. in an effective way.

Snyder and Ebeling (1992) explained in relation to competence from a functional perspective, however they use "competencies" in the plural. Other writers frequently use the term "competency" when talking about occupational competence or use it as a synonym. Therefore, Dale (1992) differentiates occupational abilities from psychosocial particularities, however they use competence and competency to execute the description in the discussion of their document to examine their abilities and skills. Hartle (1995) stated that competency as "the particularity that a person has management in the production of their work", incorporates the "competences" observable (knowledge and skills) as "summaries of competences" (traits and motives).

\section{Competency dimensions}

García Cabrero, Loredo Enríquez, Luna Serrano, and Rueda Beltrán (2008) and Bravo Salinas (2007), and Beneitone et al. (2007) in their publication of their book "Reflections and perspectives of Higher Education in Latin America", they reveal about the classification of competences:

Generic competences: ("General" or "transversal"), which are the most common in all professions and occupations; that make up the set of general knowledge that every university graduate must know (García Cabrero et al., 2008). On the other hand, in their training students have to know the different topics related to grammatical structuring. These issues are related to each other, to have efficient oral and written communication between the interlocutors, and as part of their academic training, truly training to face and serve society, according to their specialty (Beneitone et al., 2007, p. 15).
Specific competences: This type of competences are known as particles or specialization in the training of each individual (García Cabrero et al., 2008, p. 102). Distinguish training in one specialty from another; In addition, there are specializations with management of the term of specialty, which affect their personal and academic training (Beneitone et al., 2007, p. 16).

Therefore, it was formulated as a general problem: In what way is the level of written communication, linguistic deficiencies, related to the achievement of competences in students entering an Universidad Pública del Cusco? As a general objective, it was proposed: To establish the relationship between the level of written communication, linguistic deficiencies, and the achievement of competencies in students entering an Universidad Pública del Cusco. And as a specific objective: Identify the level of written communication in students entering an Universidad Pública del Cusco. Identify the level of linguistic deficiencies in students entering an Universidad Pública del Cusco. Describe the achievement of competencies in students entering an Universidad Pública del Cusco.

\section{Materials and methods}

The methodology is applicative with a quantitative research approach and the study is descriptive - correlational. First describe the variables as found in the observation; second, the level of relationship of the study variables. The research design is non-experimental because the study variables were not altered, they are detailed and as presented in the field study (Toro Jaramillo and Parra Ramírez, 2006). The study of the population is made up of the incoming students of the National University of San Antonio Abad del Cusco (UNSAAC), which add up to a total of 1406 students entering the UNSAAC in 2019 by different modalities (Unit of the Computer Center of the UNSAAC). The sample is non-probabilistic by the convenience sampling method for students from the Professional School of Education - UNSAAC., and is made up of 150 incoming students. 
The technique used is the survey, which has been prepared according to the dimensions and indicators of the variables; As an instrument used is the questionnaire, which was aimed at measuring each of the variables, having as collaborators the students entering the Professional School of Education - UNSAAC. Once the data from the surveys has been obtained, the validation of the contents is presented with the judgment of experts, who are knowledgeable people on the subject. Then, the reliability was performed with the Cronbach alpha coefficient to measure the internal of the questions, establishing the mean of the correlations between the items (Cronbach, 1951, p. 299). For the processing of the tables and figures, a Microsoft Excel program was used, and the development of descriptive statistics and inference was used the SPSS statistical software.

For the description of the variables, descriptive statistics were used and for the interpretation of the results, the balancing was performed for each of the variables; in the same way, the scale of interpreting and identifying the categories was carried out for the dimensions, which is why the evaluation scale is ordinal. The identification of the communication level takes as attributes: Very low, low, moderate and high. Meanwhile, for language deficiencies consider: Low, medium, high, very high. Finally, for the skill achievement variable, it takes the attributes of: Poor, regular, good, and very good.

The presentation of inferential analysis begins with the normality test, to observe the degree of normal distribution of the data. Likewise, the Kolmogorov-Smirnov test was used, taking into account the result of normality, that the data differ from the normal distribution (non-parametric). Therefore, it was chosen to use Spearman's Rho correlational hypothesis test.

\section{Results and discussion}

\section{Results}

The research work presents the results that were interpreted in the first instance at the descriptive level and then at the inferential level. In the first place, descriptive-relative statistics have been used, supporting as a basis the absolute frequencies and the relative frequencies of the investigated.

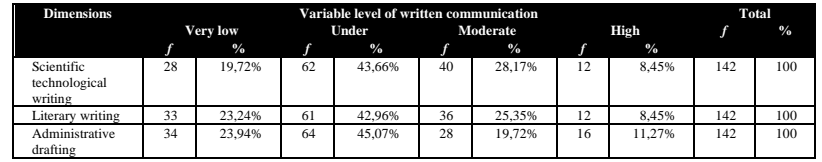

Table 1 Results of the distribution of the variable of level of written communication

Note: Data processed in the SPSS statistical program

In Table 1, the consolidated foundations of the percentages of the dimension of scientifictechnological writing are presented; $43.66 \%$ of those surveyed indicated that the level is low. Likewise, $28.17 \%$ stated that it is at a moderate level. On the other hand, $19.72 \%$ consider that they are at a low level. Therefore, most of the respondents expressed that technological scientific writing is at a low and very low level in terms of their writing of texts that they carry out in their different subjects of study; Likewise, students understand that in their learning process it is of vital importance for the activities and they need to communicate with coherence, cohesion, clarity and formality that their expressions are correct.

The consolidated results of the literary writing dimension; $42.96 \%$ of the students indicated that they are at a low level. Similarly, $25.35 \%$ revealed that it is at a moderate level. Finally, $23.24 \%$ indicated that they are at a very low level. Finally, most of the respondents expressed that if they are at a low and very low level in terms of literary writing; that is, students do not have a culture of reading some works for a reflection of the facts and events that occurred in our country, from this approach the importance of writing literary texts and the interpretation that must have coherence is valued with context.

Regarding the consolidated results of the administrative drafting dimension; $45.07 \%$ of the students stated that they are at a low level. Next, $23.94 \%$ declared that it is at a very low level. Likewise, $19.72 \%$ expressed that they are at a moderate level. In conclusion, most of the respondents expressed that if they are at a low and very low level in literary administrative writing; that is, incoming students do not yet know the administrative documents that establish an adequate wording to communicate clearly and precisely. 


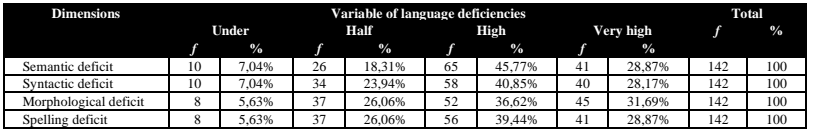

Table 2 Results of the distribution of the variable of language deficiencies

Note: Data processed in the SPSS statistical program

Table 2 shows the consolidated results of the percentages of the semantic deficit dimension; $45.77 \%$ of the surveyed students stated that it is at a high level. Likewise, $28.87 \%$ expressed that it is at a very high level. On the other hand, $18.31 \%$ indicated that they are at an average level. Finally, most of the respondents indicated on the deficiencies in semantic deficit they are at a high level and some are very high in terms of their grammatical structuring that they carry out in their monographic works and it is observed that they have difficulties in the interpretations of the meanings of words, which is related to the level of written communication. Regarding the consolidated results of the dimension of syntactic deficit; $40.85 \%$ of the surveyed students indicated that it is at a high level. Similarly, $28.17 \%$ expressed that it is at a very high level. Next, $23.94 \%$ considered that they are at an average level. In view of which, the majority of those investigated recognized that if they are in a medium and low level in language deficiencies, fundamentally in syntactic deficit; that is, students entering the university have difficulties in the constructions of their texts and likewise, in the concordance of the sentences that corresponds to a coherence, cohesion, adequacy in the writing of sentences, phrases and texts.

The consolidated results of the morphological deficit dimension; $36.62 \%$ of the surveyed students stated that they are at a high level. Next, $31.69 \%$ of respondents declared that it is at a very high level. Next, $26.06 \%$ expressed that they are at an average level. In conclusion, most of the respondents expressed that if they are at a high level and at the same time they consider the morphological deficit very high; In other words, incoming students make it difficult to recognize the different forms of words in their grammatical structure, which influence the writing of different academic, scientific and administrative texts.
The consolidated results of the spelling deficit dimension; $39.44 \%$ of the surveyed students indicated that it is at a high level. In the same way, $28.87 \%$ two expressed that it is at a very high level. Next, $26.06 \%$ consider that they are at an average level. In conclusion, most of the respondents explained that if they are at a high and very high level in language deficiencies, especially in spelling deficits; that is, students entering university have problems in grammatical conjugation or with the way of writing words, taking into account the spelling and grammar rules.

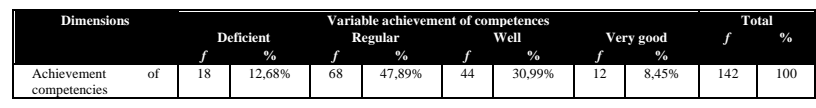

Table 3 Results of the distribution of the skill achievement variable

Note: Data processed in the SPSS statistical program.

Table 3 shows consolidated results of the percentages of the achievement of competencies dimension; $47.89 \%$ of the surveyed students stated that they are at a fair level. Likewise, $30.99 \%$ expressed that it is at a good level. On the other hand, $12.68 \%$ stated that they are at a poor level. To conclude, it shows us that the majority of the respondents indicated that the achievement of competencies is at a regular and good level in terms of their application of the text writing course, we seek to improve the generic and specific competencies of students entering the UNSAAC.

\section{Normality test}

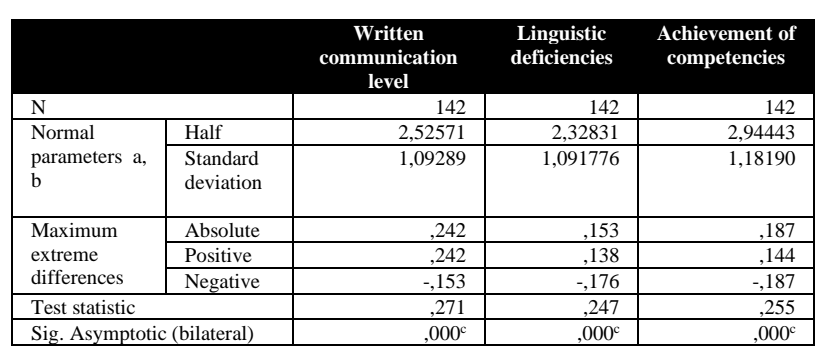

Table 4 Kolmogorov-Smirnov test for a sample Note: Data processed in the SPSS statistical program

The results that show that most of the variables have scores and do not come from a normal distribution, the quantitative variables being continuous. Therefore, we chose to use the Spearman Rho nonparametric statistical correlational hypothesis test (because it has categorical and numerical variables), since they do not meet the normality assumption. 


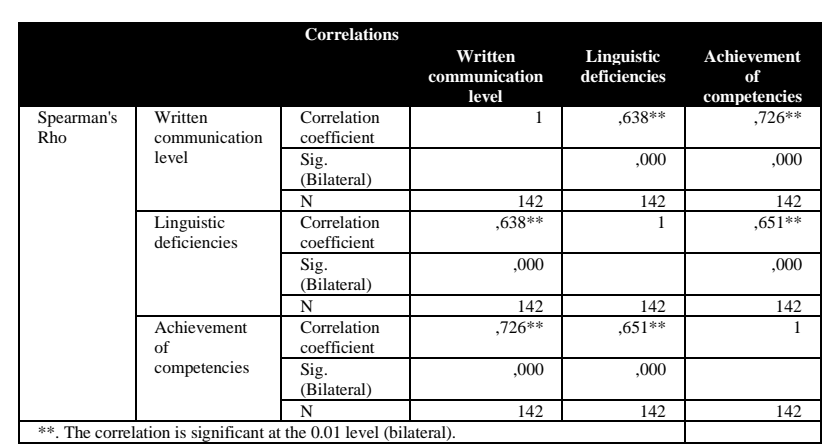

Table 5 Correlation of level of written communication, linguistic deficiencies, and achievement of competencies in incoming students

When using Spearman's Rho correlation statistical test, a moderately significant positive influence $(\mathrm{r}=0.638 * *$ and $\mathrm{P}=0.000)$ and directly proportional is demonstrated; In other words, there is an association between the level of written communication and language deficiencies in incoming students at an Universidad Pública del Cusco. Likewise, there is a good moderately significant positive relationship $(\mathrm{r}=0.726 * *$ and $\mathrm{P}=0.000)$ and directly proportional; that is, there is a direct positive relationship between the level of written communication and the achievement of competencies in incoming students at an Universidad Pública del Cusco. Finally, there is a moderately significant positive influence $(r=$ $0.651 * *$ and $\mathrm{P}=0.000$ ) and directly proportional; that is, there is a direct positive relationship between linguistic deficiencies and the achievement of competences in students entering an Universidad Pública del Cusco, since the null hypothesis is denied at $\mathrm{p}<0.01$, and the alternative hypothesis is admitted.

The correlation level is considerably positive, according to the "Spearman's Rho" value interpretation table, because the association factor is $0.638 ; 0.726$ and 0.651 . As long as there is a high level of written communication and linguistic deficiencies, there will be a good level of achievement of competencies in students entering an Universidad Pública del Cusco. It is concluded that the variables of level of written communication, linguistic deficiencies are significantly related to the achievement of competences in students entering an Universidad Pública del Cusco.

\section{Discussion}

The research work carried out a verification of the validity and reliability of the work instruments, obtaining within the accepted and favorable ranges for their application of said instruments. Likewise, the experts validated with their contribution of applicability of the instruments, which generates confidence in the use of the document.

At a descriptive level, it has allowed the surveyed students to express a medium level in the measurement of the three study variables. The results obtained show different deficiencies in written communication, linguistic deficiencies and achievement of competences; that is, in their paragraph productions they must have clarity and precision in the wording.

The students entering different Professional Schools sampled, the vast majority of which are from state educational institutions and the respective provinces. Which is observed that the National Curriculum Design of Peru is structured in a generic way and specialty teachers diversify and contextualize their context articulating to the reality of their province. Existing, disarticulation and gap with the university and educational institutions in the contents of the learning routes. In addition, the teachers of the different specialties do not work with the standards established in the educational norms, but rather they simplify the topics and this same influence in their didactic preparation of the students of the educational institutions, when they enter the universities.

It is observed that students in the Text Writing subject show these cases in newcomers who have a deficit in their academic training, in practice their quality learning is not visualized. This directly affects their use of words, production of texts, handling of a familiar language. The result is a lack of reading practice at all levels. The main factor for these students is that they have a positive attitude to improve deficiencies and project themselves in their professional training for life, with attitudes, skills and challenges that strengthen educational quality. 
At an inferential level, we analyze the fundamental purpose of study work and it has been confirmed with the existing relationship between the level of written communication, linguistic deficiencies, and the achievement of competencies in incoming students; As evidenced by the application of Spearman's Rho statistical test in Table 5, I mention a positive relationship with $\mathrm{r}=0.638 * *$, which expresses that there is a significant association; on the other hand, it is less than 5\% and consequently there is an association between the level of written communication and linguistic deficiencies in students entering an Universidad Pública del Cusco. Likewise, a good moderate significant positive association is evidenced $(\mathrm{r}=$ $0.726 * *$ and $\mathrm{P}=0.000$ ); In other words, there is a clear moderate positive association between the level of written communication and the achievement of competencies in incoming students at an Universidad Pública del Cusco. Finally, it shows a good moderately significant positive influence $(\mathrm{r}=0.651 * *$ and $\mathrm{P}=0.000)$ and directly proportional; In other words, there is a direct positive relationship between language deficiencies and the achievement of competences in incoming students at an Universidad Pública del Cusco. In conclusion, the null hypothesis (Ho) is denied, and the alternative hypothesis (Ha) is admitted, for this reason that, if there is a significant relationship between the level of written communication, linguistic deficiencies, and the achievement of competences in students entering an Universidad Pública del Cusco.

The results agree with other investigations by Gavidia Anticona (2018), where it is concluded and confirmed that if there is a positive and direct association between linguistic deficiencies and with linguistic communication; Furthermore, they expressed that the greatest deficit is in written communication, especially in semantic deficit at a regular level.

Likewise, it has been possible to compare the fundamental results with the research Bardales Balarezo (2017) and the use of the rules in the contracting procedures, there are deficiencies in the institutional regulations.
It should be noted that the results show a largely coincidence with other studies developed indicate that, the greater the presence and intensity of the level of written communication, it is related to language deficiencies; that is, the research study variables have a relationship with each other.

On the other hand, there is a similarity with the research of Rojas Saldaña (2013) who presented a doctoral thesis, with the topic: "Linguistic deficiencies in relation to written communication in students of the ISTP Sergio Bernales García de Cañete". Where it reaches the fundamental results that the semantic deficit is related to words, expressions and the syntax deficit, the grammatical structure is altered. On the other hand, they stated that there is no semantic deficit in academic work. Finally, he mentions that linguistic difficulties affect written technological scientific production, written literary production, and administrative writing. In summary, the results of this study express us about the development of the level of written communication, as a means of communication is interaction for students, which leads to the improvement of writing in different types of texts and communicative speeches.

\section{Conclusions}

The results show that, if there is a significant relationship between the level of written communication, linguistic deficiencies, and the achievement of competencies in students entering an Universidad Pública del Cusco. A Spearman Rho correlation factor $\mathrm{r}=0.638 * *$ is found, denoting the existence of a moderate effective correlation between the level of written communication and linguistic deficiencies. On the other hand, the Spearman Rho correlation factor $r=0.726 * *$ which indicates a moderate effective correlation between the level of written communication and the achievement of competences in students entering an Universidad Pública del Cusco. Finally, the Spearman Rho correlation factor $\mathrm{r}=0.651 * *$ indicates the existence of a moderate positive correlation between linguistic deficiencies and the achievement of competences in students entering an Universidad Pública del Cusco. Therefore, as long as there is a high level of written communication and linguistic deficiencies, there will be a good level of achievement of competencies in incoming students at UNSAAC. 
The level of communication in students entering an Universidad Pública del Cusco, it has been determined that $45.07 \%$ show that they have a "low" level of written communication in administrative writing. Similarly, $43.66 \%$ of those surveyed have a "low" level of written communication in scientific and technological writing. Likewise, $42.96 \%$ expressed that a level of written communication is "low" in literary writing.

The level of linguistic deficiencies in incoming students in an Universidad Pública del Cusco, has been determined in $45.77 \%$ of the respondents expressed that the linguistic deficiencies in a "high" level as a semantic deficit. Similarly, it is observed that $40.85 \%$ of the respondents indicated that the linguistic deficiencies were at a "high" level as a syntactic deficit. Likewise, it shows $39.44 \%$ of those surveyed that language deficiencies were at a "high" level as a spelling deficit. On the other hand, linguistic deficiencies at a "high" level in terms of morphological deficit with $36.62 \%$.

The variable achievement of competencies can indicate that $47.89 \%$ of students entering an Universidad Pública del Cusco have a "regular" level, 30.99\% have a "good" level of achievement of competence and $12.68 \%$ a level deficient, and only $8.45 \%$ a level of "very good" in the achievement of competencies in incoming students at the National University of San Antonio Abad del Cusco.

\section{References}

Alonso-Cortés Manteca, Á. (2002). Lingüística. Cátedra Madrid Excelente. https://dialnet.unirioja.es/servlet/libro?codigo= 168340

Arciniegas Lagos, E., \& López Jiménez, G. S. (2012). La escritura en el aula universitaria: Estrategias para su regulación. Programa Editorial UNIVALLE.

Bardales Balarezo, J. F. (2017). Deficiencias jurídicas en la aplicación del régimen de contratación administrativa de servicios (CAS) [Tesis, Universidad Nacional Hermilio Valdizan Huánuco].

http://repositorio.unheval.edu.pe/handle/UNHE VAL/2786
Beneitone, P., Esquetini, C., González, J., Maletá, M. M., Siufi, G., \& Wagenaar, R. (2007). Reflexiones y Perspectivas de la Educación Superior en América Latina Informe Final-Proyecto Tuning-América Latina 2004-2007. Universidad de Deusto.

Bravo Salinas, N. H. (2007). Competencias Proyecto Tuning-Europa, Tuning. - América Latina.

http://acreditacion.unillanos.edu.co/contenidos/ cpacitacion_docente_2semestre_2007/compete ncias_proyectotuning.pdf

Cortés Moreno, M. (2000). Guía para el profesor de idiomas: Didáctica del español y segundas lenguas. Octaedro.

Cronbach, L. J. (1951). Coefficient alpha and the internal structure of tests. Psychometrika, 16(3), 297-334.

Dale, M. (1992). Habilidades gerenciales. Legis Editores.

Estévez Fuertes, N., Gómez, J. R., \& Carbonell, M. (2011). El reto de la comunicación escrita en el siglo XXI. Quaderns de filología. Estudis lingüístics, XVI (24), 9-19.

Fonseca Yerena, M. del S., Correa Pérez, A., Pineda Ramírez, M. I., \& Lemus Hernández, F. J. (2011). Comunicación oral y escrita (1. ${ }^{\mathrm{a}}$ ed.). Prentice Hall. https://www.academia.edu/22962063/Comunic aci\%C3\%B3n_oral_y_escrita_1ed__Socorro_Fonseca_Alicia_Correa_y_Otros

García Cabrero, B., Loredo Enríquez, J., Luna Serrano, E., \& Rueda Beltrán, M. (2008). Modelo de Evaluación de Competencias Docentes para la Educación Media y Superior. Revista Iberoamericana de Evaluación Educativa, 1(3e), 97-108.

Gavidia Anticona, J. A. (2018). Deficiencias Lingüísticas en Relación con la Comunicación Escrita de los Estudiantes de Derecho y Ciencias Politicas-UNH - 2016 [Tesis, Universidad Nacional de Huancavelica]. http://repositorio.unh.edu.pe/handle/UNH/1441 
Godoy Lenz, P., \& Zilliani Illanes, M. E. (2007). Guía: NEE en el Nivel de Educación Parvularia. Necesidades educativas especiales asociadas a lenguajes y aprendizaje. Educación Especial. https://especial.mineduc.cl/recursos-apoyo-alaprendizaje/recursos-las-los-docentes/guia-neenivel-educacion-parvularia/

Gutiérrez Castillo, V. A., López Heredia, A., Salazar González, C., \& Ibarra Ramírez, L. G. (2012). Comunicación oral y escrita I (2. ${ }^{\mathrm{a}}$ ed.). Servicios Editoriales Once Ríos. https://www.freelibros.me/libros/comunicacionoral-y-escrita-i-vicente-a-gutierrez-castillo

Hartle, F. (1995). How to Re-engineer Your Performance Management Process. Kogan Page.

Martínez Martínez, I. (2002). Un estudio contrastivo español-japonés. Fundación Canon Carabela, 51, 47-67.

Martínez Solís, M. C. (2002). Estrategias de lectura y escritura de textos: Perspectivas teóricas y talleres. Universidad del Valle, Escuela de Ciencias del Lenguaje.

Mounin, G., \& Ter-Sakarian, G. (1979). Lingüística y filosofía. Gredos. https://dialnet.unirioja.es/servlet/libro?codigo= 103969

Pinales Rodríguez, D. G., \& Lagunas Beltrán, I. N. (1998). Comunicación oral y escrita. Trillas.

Rojas Saldaña, N. H. (2013). Deficiencias lingüísticas en relación a la comunicación escrita en estudiantes del ISTP «Sergio Bernales García» de Cañete [Tesis, Universidad de San Martín de Porres]. http://www.repositorioacademico.usmp.edu.pe/ handle/usmp/1145

Snyder, A. V., \& Ebeling, H. W. (1992). Targeting a Company's Real Core Competencies. Journal of Business Strategy, 13(6), 26-32. https://doi.org/10.1108/eb039524

Toro Jaramillo, I. D., \& Parra Ramírez, R. D. (2006). Método y conocimiento: Metodología de la investigación: investigación cualitativa/investigación cuantitativa ( $1 .^{\mathrm{a}}$ ed.). Universidad Eafit.
VELASCO-PALACIOS, María Dolores \& SUYO-CRUZ, Gabriel. Level of written communication, linguistic deficiencies, and the achievement of competences in incoming students in an Universidad Pública del Cusco. Journal of Teaching and Educational Research. 2021 